\title{
Measuring the Acceptance and Adoption of E-Learning by Academic Staff
}

\author{
Basheer A. Al-alak* \\ Professor of marketing, Department of Marketing and Entrepreneur Development \\ College Of Business Management and Accounting \\ Universiti Tenaga Nasional, Sultan Haj Ahmad Shah Campus, Malaysia \\ E-mail: ALALAK_2003@yahoo.com
}

\author{
Ibrahim A.M. Alnawas \\ Marketing and International Management, Reading University \\ Department of Marketing \\ Faculty of Economics and Administrative Sciences \\ AL-Zaytoonah Private University of Jordan, Jordan \\ E-mail: Alnawas_s3s@hotmail.com \\ *Corresponding author
}

\begin{abstract}
The aim of the study was to investigate Jordanian lecturers' attitudes towards the adoption of e-learning system. A number of hypotheses were formulated for this purpose. The findings of the study show that there existed positive relationship between perceived usefulness, perceived ease of use, computer knowledge, management support and intention to adopt. Whereas there existed negative relationship between normative pressure, computer anxiety and intention to adopt. Based on the results a number of recommendations were proposed, and suggestions for future studies were made.

Keywords: e-Learning; TAM; Attitudes; IT Acceptance and Adoption; Academic Staff

Biographical notes: Basheer A. Al-Allak is a Professor in the Department ofMarketing and Entrepreneur Development, College Of Business Management and Accounting (COBA), Universiti Tenaga Nasional. He earned his $\mathrm{PhD}, \mathrm{MSc}$ and $\mathrm{BSc}$ from UK universities. He has over 30 years of marketing and related working experience. He has already published over 30 papers in international journals.
\end{abstract}

\section{Introduction}

The advancements of Information and multimedia technology, and the use of internet as a new way of teaching, has a made a revolutionary changes in the traditional teaching process (Wang et al. 2007; Tao et al., 2006). Using electronic media such as computer videoconferencing, audio, internet, interactive $\mathrm{TV}$ and satellite as medium to conduct electronic learning (e-learning), has fueled the opportunity to introduce a new learning environment and scenarios to potential benefiters (Hung and Cho, 2008). New institutional designs and infrastructures associated with a new didactic framework and 
learning strategies need to be established to provide learners with the required skills and competences for their future careers (Kelz, 2009). It is argued that the achieved outcomes from the traditional education and training programs are quite often far from ideal (Chen and Hsiang, 2007), and hence, institutions have to find a new way of training and learning and developing a new system to manage the flow of knowledge (Liu and Wang, 2009). Tham and Werner (2005) demonstrated that higher education sector must keep abreast with technological changes through providing ideal learning environment in order to respond to changing demand. Furthermore, to stay competitive in such a dynamic learning environment, many western educational institutions have devoted a huge amount of resources to develop their e-learning system (Ling and Moi, 2007. On the contrary, the e-learning system is still in its infancy phases within the Middle Eastern educational setting (Ali and Magalhaes, 2008). Teachers may adopt the old way (traditional classes) as the right way, and hence, may believe that this is the right way of teaching and doing things (James, 1997). Such perception might be held by some teachers in the Middle East, due to the lack of clear guidelines since e-learning is still infant. Although e-learning system consists of three elements; technology and infrastructure, instructors/teachers, and students, teachers or instructors are perceived to be one of the main factors that contributes to the success of such learning process, since his/her knowledge about using technology and attitudes toward using such technology play a vital role in adopting the technology in question and in this case adopting e-learning (Swan et al., 2002; Bonk et al. 2002; Keller et al., 2003; Hovermill, 2003).

However, most of the previous studies have examined the concept of e-learning from a western perspective, and little attention has been paid to the investigation of such concept in the Arab world. Specifically, as far as the current researchers' knowledge is concerned, no previous studies were found that focus on e-learning in eastern countrieswith the exception of a study conducted Ali and Magalhaes, (2008) - particularly in Jordan. In addition, although the internet penetration in Jordan has reached around 30\% in 2009 and it is expected to exceed $50 \%$ by 2010 (The Jordan Times, 2009), no Jordanian university was found to use e-learning system as a learning tool. Despite the existence of numerous e-learning initiatives in Jordan, implementation of such initiatives is in infant stage. Therefore, our study attempts to examine why such initiatives are not properly implemented. Based on literature review, the paper has attempted to identify different variables that may help explain the reasons behind the reluctance to implement such initiatives. Therefore, the primary purpose of this paper is to investigate the adoption of e-learning system in Jordanian educational setting. More specifically, the authors of this paper intend to measure Jordanian academicians' attitudes toward the adoption of e-learning system. The importance of the study lies in the fact that it is the first exploratory research that addresses the acceptance and adoption of e-learning by academic staff. The contribution of this study is manifested in developing a model which could be used in future studies to better explore the issue of e-learning adoption in the Middle East.

\section{Literature Review}

\subsection{The Concept of E-learning}

According to Wentling et al. (2000) e-learning "is the acquisition and use of knowledge distributed and facilitated primarily by electronic means". Liu and Wang (2009) in their review of the definitions of e-learning found that the characteristics of e-learning process 
are mainly based on the internet; information disseminates and knowledge flows in the form of network courses; worldwide sharing of learning resources; and flexibility of learning (no constrains) as a virtual learning environment is created to overcome distance and time issues. This new learning environment which is based on electronic networks has enabled learners in both organizations and universities to receive individualized support and to have learning schedules that is more convenient to them and separate from other learners (Tao et al. 2006). Such environment may facilitate a high level of interaction and collaboration between instructors and peers than traditional learning environment. Interaction which is essential in the e-learning process can enable learners to contact instructors anytime when necessary (Ally, 2004) and communicate with instructors beyond office hours and scheduled class time (Hung and Cho, 2008).

Liaw et al. (2007) show that e-learning in the academic arena which is characterized by the use of multimedia constructs made the learning process more active, enjoyable and interesting. Cost, service, quality and speed are believed to be the main constructs (Hammer and Champy, 2001) that have made e-learning the most promising educational technology (Liaw et al., 2007). It is perceived that e-learning can enable students at a higher educational level to obtain their education in parallel with pursing their personal goals and maintaining their own careers, without a need to attend classes and be subjected to a rigid schedule (Borstorff and Lowe. 2007). To support this line of thought, Kartha (2006) report that the number of online courses has increased dramatically due to the attained benefits for both universities and learners. It was also estimated that more than 500.000 students had obtained their certificates via online programs in 2002 (Symonds, 2003).

The important role that e-learning plays in accessing, collecting, analyzing and transferring of information and knowledge (Bates 2005), the vital contribution to the progress of academic staff and students, and the improvements in the quality of teaching methods and learning management system (Begiievic et al. 2007), have resulted in increasing the popularity of e-learning in different educational institutions and organizations (Sul ${ }^{-}{ }^{-} \mathrm{c}, 2007$ ). The continuous pressure to cut costs through decreasing the number of the hired academic staff, and the considerable amount of efforts that are exhibited by universities to increase enrollment rates through offering flexible schedules that suit different learners needs, have also spurred the need for universities to embark the concept of e-learning (Zapalska et al. 2003).

However, for e-learning to be successful, Campbell \& Swift (2005) demonstrate that both instructors and students have to change their attitudes, belief, behavior, perspective and habits in order to successfully adopt the use of technology. Brower (2002) states that teachers fear and unwillingness to adopt e-learning as a new way of teaching is attributed to their feeling. The argument is that in order to teach, then they have to touch students and be close to them, and hence, using e-learning may dramatically change the way they teach which is mainly based on getting in contact with learners. Dabholkar (1994) hypothesized that people simultaneously have positive/negative attitudes or beliefs towards technology. A positive belief or attitude would foster individual acceptance towards technology, while a negative attitude or belief might hold them back. Since e-learning is mainly based on the use of technology to deliver content via internet, it has been concluded that e-learning is regarded as radical and challenging for learners, teachers and administrators(Rossiter, 2007), and hence, teachers may resist adopting the use of such system.

Different skills which instructors have to be equipped with, are also found to influence his/her attitude towards the adoption of e-learning system. Bonk (2000) points 
out that instructors should have different skills and play different roles in order to be able to adopt the use of technology in teaching. First, instructors need to understand the application software and the implications of technology in order to be able to adopt such technology and enhance students learning experience. Second, instructors need to be able to design online courses which should make students more interesting and interactive, and hence, instructors should adopt the right tool, not just the available one. Finally, instructors have to play a social role to keep students motivated and increase their level of learning. Such skills and roles may be perceived as obstacles which may hinder instructors from utilizing e-learning.

\subsection{Previous research}

Early research has shown (e.g. Rosen \& Weil, 1995) that teachers are unwilling to use computer-based teaching due the lack of teaching experience with information and communications technology and the lack of technical support for teachers. Teachers' perceptions and personal and psychological factors were also found to have a main influence on instructor' attitude to adopt the use of technology compared to traditional classes (Robertson et al. 1996). Shurville and Browne (2006) find that there are many drivers for educational institutions to adopt e-learning systems; facing global competition, personalizing learning, supporting lifelong and work-based learners, reducing costs and addressing environmental sustainability. Ally (2004) concludes that methods and ways of teaching as well as student evaluations methods and testing are much more important than the use of Information and communication technology in education. Russell (2001) and Kartha (2006) investigated the effectiveness of e-learning compared to traditional and found no statistical significant differences between the two approaches. Zemsky (2007) found out that users' acceptance of technology of distance learning was not the only influencer on the adoption of the e-learning system. The author concluded that users' attitude towards computer, prior information and communication technology experience and state of technology readiness, had a significant effect on the adoption of e-learning system. Similar results were found in Concannon et al (2005) study. Duke (2002) showed that educational institutions were more resistant to change and hence the adoption elearning system compared to firms.

Webster and Hackley (1997) and Dillon and Morris (1996) concluded that educators' attitudes towards a technology and their control over the technology had a significant effect on the learning outcomes. Singleton et al. (2004), pointed out that instructors preferred traditional classes rather than delivering content via the internet because they were more familiar with the former one and learning environment. Ong \& Lai (2006) and Tung \& Chang (2008) found that the perceived usefulness and the perceived ease of use of e-learning system had a significant effect on the behavioral intention to use that system. Pituch and Lee (2006) demonstrated that having a distance learning system within the educational institution setting would not automatically lead to its use. Porter and Donthu (2006) reported that people's experience, personality and cognitive factors lead to form a particular belief about their ability to perform a certain thing, and therefore, people would avoid learning something new because of the perceived difficulty and risk associated with performing that thing. Zhao \& Frank (2003) found that the lack of access to internet from home was the main barrier to use technology in the teaching process. The authors also concluded that educators who had a positive perception toward the perceived value of using computers were more likely to embark the concept of distance learning. Becker (1999) found educators who had student-centered beliefs were more likely to use technology. 


\section{Hypotheses Development and Proposed Model}

\subsection{Theory of a reasoned behavior (TRA) and Technology Acceptance Model (TAM)}

Theory of a reasoned behavior (TRA) was originally proposed by Fishbein \& Ajzen in 1975 to understand behavior and predict outcomes. The main assumption of TRA is that a person takes into consideration the implications of his/her action before s/he decides to actually engage or not in certain behavior. It also posits that the main determinant of a person's behavior is behavior intent. Ajzen \& Fishbein (1980) point out that a person's attitude is determined by his/her perception about the expected consequences of performing the behavior and the assessment of those consequences, and hence, if a person's intent is strong, then it is expected that the behavior will be actually performed. Therefore, the primary concern is to identify the underlying factors of the formation and change of behavioral intent. Besides, Davis (1989) proposed a technology acceptance model (TAM) which is based on TRA. The premise of TAM is that people behavioral intention to accept and actually use a certain technology is determined by two constructs namely; perceived usefulness and perceived ease of use. User's attitude and belief as proposed by TAM is perceived to be an important factor which influences the use of new technology. People who have positive attitudes toward information technology will have higher acceptance of the use of the technology in question, compared to people who have negative attitudes toward that technology. Many empirical research (e.g. Davis et al. 1989; Agarwal \& Karahanna \& Straub, 1999; Venkatesh et al. 2003, 2007) have been carried out and they have shown a support for the favor of TAM.

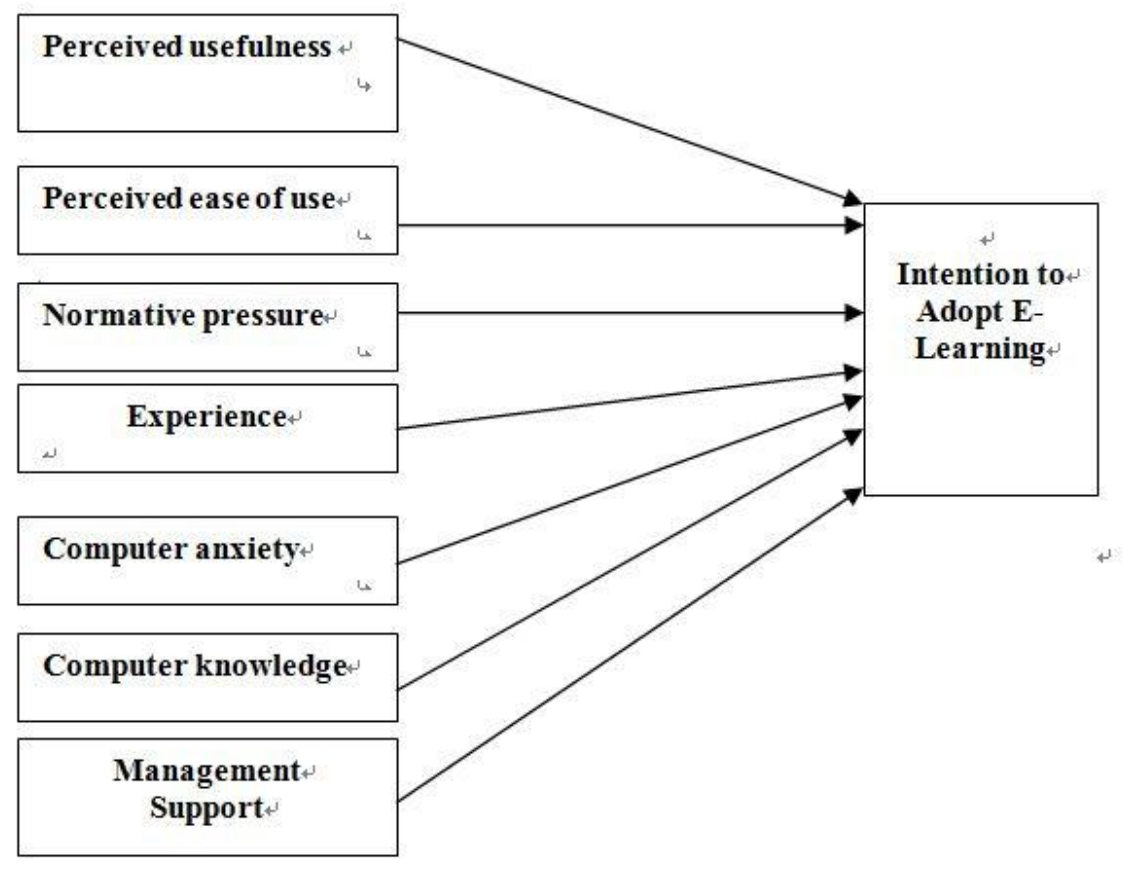

Figure 1. The study model 
However, for the purpose of model development of this current research, two fundamental measures namely perceived usefulness and perceived ease of use were employed and five additional measures were added into TAM, experience (Parthasarathy and Bhattacherjee, 1998; Cho and Kim; 2002), computer anxiety and computer knowledge (Venkatash and Bala, 2008; Rovai and Childress, 2002; Delcourt and Kinzie, 1993), normative pressure (Nysveen et al. 2005), and management support (Chatterjee et al. 2002; Liang et al. 2007), which all have proven to be important factors that influence users behavioral intentions toward adopting a new system.

Figure 1. summarizes the relationship between the independent variables that may influence behavioral intention and actual use of technology.

\subsection{Perceived usefulness}

Davis (1989) defined perceived usefulness as the extent to which a user believes that utilizing a certain system would influence his/her job performance and productivity positively (i.e. providing timely information). From a theoretical perspective, TAM suggests that people intend to act before they actually act, and the perceived usefulness and attitudes towards the information technology are the main predictors of behavioral intention. A significant body of literature in different academic fields (e.g. Legris et al. 2003; Davis et al., 1992; Koufaris, 2002; Ong \& Lai, 2006; Cheong and Park, 2005) have stressed the importance of perceived usefulness in accepting new technology. Igbaria et al. (1997) state that perceived usefulness has an effect on individuals' technology acceptance because of the reinforcement value of outcomes. Users, who believe in a positive use-performance relationship, will lead to foster the acceptance of technology (Davis, 1989) and that will influence behavioral intention to use that technology (Sun et al. 2008). Tung \& Chang (2008) in their "an empirical investigation of students' behavioral intentions to use the online learning course websites", concluded that when learners perceived e-learning as useful, they were more likely to accept and actually learn online. In the same vein, the perceived usefulness from educators point of view (i.e. greater control over work, improve job performance, save time, accomplish tasks more quickly, enhance effectiveness) may influence their behavioral intention to adopt elearning system. Therefore, the following hypothesis is formulated:

H1: There is positive relationship between perceived usefulness and behavioral intention. It is expected that lecturers who perceive e-learning system as useful will influence their intention to adopt such system positively.

\subsection{Perceived ease of use}

Davis (1989) defined perceived ease of use as the extent to which people believe that using certain system would be effortless. From behavioral decision making point of view, people usually try to minimize effort in their behavior (Igbaria and Iivari, 1995). Venkatesh (2000) point out that users would form early perceptions of perceived ease of use of a particular system based on their general beliefs with regard to that system and its usages. Venkatesh \& Morris (2000) demonstrate that perceived ease of use is a function of users' evaluation of the effort involved in the process of learning. It is believed that perceived ease-of-use helps in reducing the uncertainty of innovations, leading individuals to adopt the technology in question (Elliott and Fu, 2008). Porter and Donthu (2006) hypothesize that that users will avoid learning something new due to the perceived difficulty and risk associated with learning that thing. Wang et al. (2003) and Amin (2009) report that perceived ease of use has a significant effect on behavioral and usage 
intentions. Ong and Lai (2006) found that perceived ease of use had a significant influence on the behavioral intention of students to use e-learning. Consequently, perceived ease of use in e-learning (i.e. less mental effort, less frustrating, flexible, less rigid, easy to understand, helpful guidance in performing tasks) may influence Jordanian lecturers intention to adopt e-learning system. Therefore, the following hypothesis is formulated:

H2: There is positive relationship between perceived ease of use and behavioral intention. It is expected that lecturers who perceive e-learning system to be easy will influence their intention to adopt such system positively.

\subsection{Normative pressure}

According to the theory of reasoned behavior (Fishbein \& Ajzen, 1975), a person's intention to behave in a certain way is contingent upon the attitude toward performing the behavior in question and the social pressure on him/her to behave in that way (subjective norm). This suggests that attitudes and subjective norms differ according to the person involved and behavioral context. Normative pressure could be defined as "a person's perception that most people who are important to her/him think s/he should or should not perform the behavior in question" (Fishbein and Ajzen 1975, p. 30). Normative pressure is relevant to this research because it refers to the degree to which members in a society or with educational setting (i.e. administrators and university stakeholders) influence others behavior to perform a particular behavior. Previous research (e.g. Kleijnen et al. 2004; Hung et al. 2002) found a strong support for the relationship between normative pressure and behavioral intention. Kleijnen et al. (2004) reported that normative pressure had a significant effect on people intention to use wireless finance. Chang and Cheung (2001) concluded that normative pressure was significant to intention to use the internet at workplace. Based on the reviewed literature the following hypothesis is formulated:

H3: Normative pressure has a positive effect on behavioral intention to adopt e-learning system.

\subsection{Experience}

Experience is "an accumulative memory process of all kinds of senses and feelings" (Oi et al. 2009. p. 394). People experience with the use of technology has been defined "the amount and type of computer skills a person acquires over time" (Smith et al. 1999, p. 227). McGeoch and Irion (1952) state that a person's prior knowledge and experiences influence their ability to learn new concepts. Bhattacherjee \& Premkumar (2004) demonstrated that people experience plays a vital role in their initial acceptance towards a system in question. Prior experience was theorized to be as a facilitator for the learning process, and hence, making a new technology easy to be adopted (Karahanna et al. 2006). Venkatesh \& Bala (2008) state that when a system (information technology) is reliable and flexible, there is a highly likelihood that the people will have less "system-related anxiety", and this is because of their prior experience. Cassidy and Eachus (2002) investigated experience with the use technology through using a single item and a 5-point Likert scale. Research has shown that experience with the use of technology has an influence on intention to use and actual use of information technology (Thompson et al., 2006; Karahanna et al. 1999; Parthasarathy and Bhattacherjee, 1998). In their recent an empirical research, Ball and Levy (2009) found that experience had a significant effect on instructors' intention to use emerging educational technology. Accordingly, it is expected that Jordanian educators with prior experience in the use of information technology will 
have positive attitudes toward the behavioral intention to adopt e-learning system. Therefore, the following hypothesis is formulated:

H4: There is a positive relationship between experience to the use of information technology and the behavioral intention to adopt e-learning system

\subsection{Computer anxiety \& Computer knowledge}

Computer anxiety has been defined as the degree of "an individual's apprehension, or even fear, when she/he is faced with the possibility of using computers" (Venkatesh, 2000, p. 349). Venkatesh, 2000 hypothesized that computer anxiety would lead users to form negative attitudes toward their behavioral intention to adopt technology. Delcourt and Kinzie (1993) state that educators may perceive that using computers might lead to improve the effectiveness and the efficiency of teaching process. However, they may not choose to use such technology in delivering course contents due to the lack of confidence in their ability to use computers or because of their fearing to deal with computers, or simply because they do not want to use computers. In the e-learning environment, educators have to interact and communicate with their students through using technology (computers). Educators who are anxious or uncomfortable with using computers would be more reluctant to adopt e-learning system (Fuller et al. 2006). Yang et al. (1999) demonstrate that computer anxiety is one of the main factors for limited instructors' technology acceptance. Prior research (e.g. Keeler \& Anson, 1995; Todman and Monaghan, 1994) has shown that computer anxiety is associated with avoidance and a decrease use of information technology. On the other hand, Loyd \& Gressard (1984) point out that computer usefulness and computer confidence due to prior knowledge with using computer would lead to form positive attitudes toward the acceptance of using technology. Howard (1986) concludes that having adequate knowledge about computers would also lead to a positive attitude toward that technology. In e-learning environments where educators have to interact with their students, it is expected that educators who fear the use of computers will have a negative effect on their behavioral intentions to the adoption of e-learning. On the other hand, it is expected that educators who have an adequate level of knowledge towards using technology will have a positive effect on the adoption of e-learning system. Therefore, based on the grasp of the literature discussed above, the following hypotheses are formulated:

H5: There is a negative relationship between the computer anxiety and behavioral intention to adopt e-learning system.

H6: There is a positive relationship between computer knowledge and behavioral intention to adopt e-learning system.

\subsection{Management support}

Management support is defined as the extent to which a person "believes that organizational and technical resources exist to support the use of the system" (Venkatesh et al., 2003). Venkatesh \& Bala (2008) demonstrate that when users hold a strong believe with regard to the availability of organization resources, technical and managerial support, then, that will facilitate the adoption of technology in question. Research has shown a significant relationship between management support and intention to adopt and actual of a particular system or technology (e.g. Liang et al. 2007). Previous research has also demonstrated that management support is one of the most critical and important factors which contributes to the success of a complicated system (e.g. Chatterjee et al. 2002). 
Accordingly, it is expected that in the e-learning environment, educators who believe that they will have a management support with regard to the implementation of e-learning system, which requires changes in university structures and educators roles, will have a positive effect on the adoption of e-learning system, and hence, the following hypothesis is formulated:

H7: There is a positive relationship between management support and intention to adopt e-learning system.

\section{Methodology}

Previously scales which have proven to be valid were employed to measure all constructs of the research proposed model. Some items of the scale were modified to the context of e-learning system acceptance. Six items to measure perceived usefulness and five items to measure perceived ease of use were adopted from Davis (1989) and Moore and Benbasat (1991). Normative pressure was measured using four items adopted from Davis et al. (1989) and Venkatesh and Davis (2000). Five items to measure experience with the use of technology were adopted from Igbaria and Iivari (1995) and Cassidy and Eachus (2002). Computer anxiety and computer knowledge constructs were measured using five and four items respectively adopted from Fuller et al. (2006), and Rovai and Childress (2002). Management support was measured using 4 items adopted from Venkatesh \& Bala (2008). Finally, three items were adopted from Venkatesh and Davis (2000) to measure intent to use.

The required primary data was collected through a self administrated questionnaire which was originally developed and employed for the purpose of the study. Questions asked respondents to rate their degree of agreement using a 5-point Likert scale. A pilot study was first conducted to improve questionnaire structure and content. To achieve this purpose, thirty questionnaires were sent to experts and academicians who work in IT and marketing departments in different Jordanian universities. Several statements were revised based on the input from the academicians and experts, and the comments were considered in the final version. Of the original 55 statements, 43 were then selected and used for the research instrument. A random sample of 10 public and private Jordanian universities namely; Jordanian University, Yarmok University, Alalbayet University, Alhussien Bin Talal University, Moa`tah University, Al-esra'a University, Al-zaytoonah University, Petra University, Jerash University, and Philadelphia University was used. The sample contained 1000 respondents. Approximately, 100 questionnaires were distributed to lecturers in different departments of university. Out of the 1000 distributed questionnaires a total of 832 or a response rate of $83 \%$ was returned. After removing the invalid questionnaires, 799 questionnaires were used in the analytical stage. The 33 questionnaires were considered invalid because respondents skipped many items. The period of distributing the questionnaire lasted from 10th of May 2009 until the 1st of October 2009. The process of distributing the questionnaire was drop-off approach (Aaker et al. 2004). Based on the logic of this method, the researchers hand delivered the questionnaire randomly to lecturers in the above mentioned universities after explaining to them the purpose of the study, the required procedure to fill out the questionnaire and answering any question with regard to any of the questionnaire's statements. The data obtained from the survey were analyzed for frequency analysis. Among respondents, male was $72 \%$ (577) and female was $28 \%$ (299). 
EQS_ software (Byrne 1994) was employed for statistical treatment. A two-step structural equation modeling was used to test the current research model based on Anderson and Gerbing (1988) recommendations. A confirmatory factor analysis (CFA) was used to purify the measurement model in order to determine reliabilities, convergent and discriminant validity, followed by evaluating the structural model to test the previously stated hypotheses. The purification process was conducted through dropping items which did not have good item reliability. The overall model fit was evaluated through using comparative fit index (CFI), incremental fit index (IFI), root-mean-square error of approximation (RMSEA), and non-normed fit index (NNFI).

\section{Results}

\subsection{Confirmatory factor analysis}

The results of confirmatory factor analysis which was employed to purify the measurement model to compute reliabilities, convergent and discriminant validity show that all items have significant and large loading on their corresponding factors. The results are displayed in table 1 . The reliability test of all measured items ranged from .75 to .92. The cut-off point is generally 0.6 (Hair et al., 1992). Since all values were in between 0.75 and 0.92 and all above 0.74 the construct in our model resulted in being very reliable, (see table 1 ).

Table 1. Standardized factor loadings, construct reliability, Cronbach's alpha(Part 1)

\begin{tabular}{|l|l|l|l|}
\hline Items & Standardized Loading & $\begin{array}{l}\text { Construct } \\
\text { Reliability }\end{array}$ & $\begin{array}{l}\text { Cronbach's } \\
\text { Alpha }\end{array}$ \\
\hline Perceived Usefulness & & .81 & .86 \\
\hline PU*1 & .82 & & \\
PU2 & .84 & & \\
PU3 & .92 & & \\
PU4 & .65 & & \\
PU5 & .77 & & \\
PU6 & .81 & .85 & \\
\hline Perceived Ease of & & & \\
Use & .82 & & \\
\hline PEOU*1 & .79 & & \\
PEOU2 & .84 & & \\
PEOU3 & .90 & & \\
PEOU4 & .71 & .77 & \\
PEOU5 & & & \\
\hline Normative Pressure & .77 & & \\
\hline NP*1 & .86 & & \\
NP2 & & & \\
\hline
\end{tabular}




\begin{tabular}{|l|l|l|l|}
\hline NP3 & .88 & & \\
NP4 & .81 & .79 & \\
\hline Experience & & & .88 \\
\hline E*1 & .87 & & \\
E2 & .76 & & \\
E3 & .77 & & \\
E4 & .81 & & \\
E5 & .82 & & \\
\hline
\end{tabular}

Table 1. Standardized factor loadings, construct reliability, Cronbach's alpha(Part 2)

\begin{tabular}{|c|c|c|c|}
\hline Items & Standardized Loading & $\begin{array}{l}\text { Construct } \\
\text { Reliability }\end{array}$ & $\begin{array}{l}\text { Cronbach's } \\
\text { Alpha }\end{array}$ \\
\hline Computer Anxiety & & .80 & .76 \\
\hline $\mathrm{CA}^{* 1} \mathbf{1}$ & .69 & & \\
\hline CA2 & .74 & & \\
\hline CA3 & .85 & & \\
\hline CA4 & .77 & & \\
\hline CA5 & .83 & & \\
\hline $\begin{array}{l}\text { Computer } \\
\text { Knowledge }\end{array}$ & & .88 & .92 \\
\hline CK*1 & .91 & & \\
\hline CK2 & .84 & & \\
\hline CK3 & .87 & & \\
\hline CK4 & .66 & & \\
\hline $\begin{array}{l}\text { Management } \\
\text { Support }\end{array}$ & & .78 & .82 \\
\hline MS*1 & .89 & & \\
\hline MS2 & .68 & & \\
\hline MS3 & .73 & & \\
\hline MS4 & .80 & & \\
\hline Intention & & .84 & .89 \\
\hline INT*1 & .87 & & \\
\hline INT2 & .83 & & \\
\hline INT3 & .88 & & \\
\hline
\end{tabular}




\section{$P U=$ Perceived usefulness \\ $N P=$ Normative pressure \\ CA= Computer anxiety}

MS= Management Support
PEOU = Perceived ease of use

$E=$ Experience

CK= Computer knowledge

INT= Intention to adopt

The average variance extracted and the shared variance was computed to test convergent and discriminant validity. The results are displayed in table 2 . The results however, show that the amount of average variance extracted ranged from .55 to .81 , and the shared variance was below the amount of average variance extracted. By having such results, then convergent and discriminant validity are met. The evidence suggests that our scale had adequate measurement properties (see table 2).

Table 2: Statistics and Discriminant Validity Matrix

\begin{tabular}{|c|c|c|c|c|c|c|c|c|c|c|}
\hline Construct & $\overline{\mathbf{P U}}$ & $\overline{\text { PEOU }}$ & $\overline{\text { NP }}$ & $\mathbf{E}$ & CA & $\overline{C K}$ & RTC & MS & INT & $\overline{\mathbf{A A}}$ \\
\hline PU & .55 & .15 & .43 & .20 & .34 & .28 & .03 & .19 & .22 & .39 \\
\hline PEOU & .09 & .76 & .11 & .45 & .17 & .24 & .26 & .07 & .10 & .35 \\
\hline NP & .16 & .01 & .61 & .32 & .11 & .01 & .25 & .18 & .29 & .35 \\
\hline $\mathbf{E}$ & .28 & .14 & .29 & .59 & .02 & .36 & .16 & .04 & .18 & .27 \\
\hline CA & .03 & .01 & .19 & .11 & .68 & .23 & .10 & .09 & .09 & .17 \\
\hline CK & .12 & .30 & .18 & .24 & .08 & .53 & .33 & .07 & .01 & .15 \\
\hline MS & .21 & .18 & .39 & .23 & .23 & .07 & .14 & .63 & .31 & .19 \\
\hline INT & .05 & .01 & .12 & .36 & .24 & .08 & .33 & .20 & .81 & .39 \\
\hline
\end{tabular}

Bold numbers (the diagonal elements) reflect the average variance extracted between the constructs. For discriminant validity, diagonal elements should be larger than offdiagonal elements.

\subsection{Over all model fit}

For model fit assessment, several diagnostics were used to judge the simultaneous fit of the measurement and structural models to the data collected for the study. The comparative fit index (CFI) was 0.94. Other diagnostics such as root mean square residual (RMSR) was 0.031 . This model had the normed fit index (NFI) value of 0.98 and incremental fit index (IFI), value of .93. The structural model fit is within an acceptable level (see e.g. Hart and Porter, 2004). 


\subsection{Structural model analyses}

The previously stated hypotheses were tested using EQS. Of the 7 relationships, 6 are statistically significant in the expected direction (see Table 3). The results will be stated in order. Perceived usefulness $(\beta=.28, \mathrm{p}<.01)$, perceived ease of use $(\beta=.36, \mathrm{p}$ $<.01)$, normative pressure $(\beta=-.22, \mathrm{p}<.01)$, experience $(\beta=.46, \mathrm{p}<.01)$, computer anxiety $(\beta=-.06, \mathrm{p}<.01)$, computer knowledge $(\beta=.41, \mathrm{p}<.01)$, and management support $(\beta=.31, \mathrm{p}<.01)$. Only normative pressure was not supported. Table 3 shows support/not support hypotheses.

Table 3. Summary of hypotheses test

\begin{tabular}{|c|c|c|}
\hline Hypotheses & Accepted/Rejected & $\beta, \mathrm{p}<.01$ \\
\hline $\begin{array}{l}\text { H1: There is positive relationship between perceived usefulness } \\
\text { and behavioral intention. }\end{array}$ & Accepted & $.28(3.42)$ \\
\hline $\begin{array}{l}\mathrm{H} 2 \text { : There is positive relationship between perceived ease of use } \\
\text { and behavioral intention. }\end{array}$ & Accepted & $.36(6.82)$ \\
\hline $\begin{array}{l}\text { H3: Normative pressure has a positive effect on behavioral } \\
\text { intention to adopt e-learning system. }\end{array}$ & Rejected & $-.22(3.02)$ \\
\hline $\begin{array}{l}\text { H4: There is a positive relationship between experience to the use } \\
\text { of information technology and the behavioral intention to adopt e- } \\
\text { learning system }\end{array}$ & Accepted & $.46(8.92)$ \\
\hline $\begin{array}{l}\text { H5: There is a negative relationship between the computer } \\
\text { anxiety and behavioral intention to adopt e-learning system. }\end{array}$ & Accepted & $-.06(1.10)$ \\
\hline $\begin{array}{l}\text { H6: There is a positive relationship between computer } \\
\text { knowledge and behavioral intention to adopt e-learning system }\end{array}$ & Accepted & $.41(8.17)$ \\
\hline $\begin{array}{l}\text { H7: There is a positive relationship between management } \\
\text { support and intention to adopt e-learning system. }\end{array}$ & Accepted & $.31(4.66)$ \\
\hline
\end{tabular}




\section{Discussion and Conclusion}

The objective of this study was to measure lecturers' attitudes toward the adoption of elearning system as a new way of teaching. The theoretical basis of the current research was derived from behavioral intention and technology acceptance models. The model has been adapted to reflect determinants relevant to lecturers' attitudes to the adoption of elearning system. Structural equation modeling was used to test the validity of the research model and the relationship among its constructs. The findings of this empirical study show that all formulated hypotheses were in the same direction as was hypothesized in the study except the third hypothesis which states that there is a positive relationship between normative pressure and the adoption of e-learning (see table 1). The findings of the current research show that perceived ease of use and perceived usefulness were significant, but not the strongest constructs to predict behavioral intention. Experience and computer knowledge were the strongest indicators among other constructs to predict behavioral intentions. Chin (1998) concludes that when a new technology is compatible with users' prior experience, work style and existing work practices then it is easy to be adopted, and hence, this could explain why experience was among the strongest indicators of behavioral intention to adopt e-learning system, since experience interferes with lecturers' ability to learn new concepts. Computer knowledge was the second strongest indicator of behavioral intention, and this can explain why computer anxiety was significant and has a negative effect on the intention to adopt e-learning system. The justification for that might be that lecturers' computer knowledge help them to over the difficulties associated with adopting e-learning system, and hence, form positive affective reactions and attitudes toward the adoption of e-learning. Management support was also found to have a significant and positive impact on lecturers' attitudes to adopt e-learning system.

Venkatesh and Bala (2008) state that the implementation of a complex system often needs substantial changes to organizational structure, employees' roles and jobs, control and coordination mechanisms, and work processes, and hence, lecturers may believe that a university support in the form of commitment and communication and providing the required infrastructures and training which are related to the implementation of e-learning system will accelerate the adoption of such system. This applies to the case of Jordan were staff welcome management support regarding it as an incentive to accelerate the adoption of e-learning system. The effect of normative pressure on lecturers' attitudes was not as expected. Wechsler et al. (2003) state that individuals might perceive pressures from others as an attempt to dissuade them from using the technology in question, and therefore, this may result in opposite impact compared to what was intended. Lecturers may receive pressures from a university as a de-motivation to them since the concept of e-learning is not well conceptualized and understood within the Jordanian university setting and hence, lecturers may resist changing their work routines since the attained benefits of e-learning system may not fully understood.

The findings of the current research explain the reasons behind the failure to adopt e-learning initiatives in Jordan, despite teachers' positive attitudes towards the adoption of e-learning. The justification for the reluctance to adopt is attributed to (1) the improper deployment of the necessary infrastructure and equipment for sparking the growth of e-learning; (2) lack of specific training at all levels particularly, teachers, students and trainers; (3) the absence of the necessary conditions for the development of quality educational contents and services; and (4) not hastening the networking and corporation at the national level. Furthermore, the efforts to introduce e-learning system requires more than just government, it needs a partnership with the private sector, 
international organizations like World Bank, and multinational companies that have come to view Jordan as a model of reforms.

Several recommendations can be made to increase lecturers' acceptance of elearning and its use. First, university management needs to support its academic staff through providing the required infrastructures and collaborate and communicate with them in order to reduce their fear or unwillingness to adopt e-learning system due to the substantial changes that e-learning system will bring to lecturers work processes. Educational institutions should make a systematic effort to provide lecturers with training on how to use e-learning system effectively. Courses should be given to lecturers to explain them the obtained benefits of adopting e-learning system, and how such system can effectively support their educational objectives. As computer anxiety has been found to have a strong and negative effect on intention to adopt e-learning system, training should be designed to increase lecturers' computer knowledge. Finally, educational institutions should take advantage of those who have experience with the use of information technology and utilize them in assisting those who have no such previous experience.

\section{Suggestions for future research}

Further research should be carried out to identify other factors that may influence lecturers' attitudes toward the adoption of e-learning system. The included sample of lecturers was investigated, without regard to their academic rank, or demographics. Future research needs to examine the effect of age and years of teaching as demographic characteristics on their acceptance level towards e-learning system.

\section{References}

1. Aaker, D., Kumar, V., \& Day, G. S. (2004). Marketing Research, (8th edition). John Wiley \& sons, Inc., New York, P. 259.

2. Agarwal, R., \& Karahanna, E. (2000). Time flies when you're having fun: Cognitive absorption and beliefs about information technology usage. MIS Quarterly, 24, 665-694.

3. Ajzen, I., \& Fishbein, M. (1980). Understanding Attitudes and Predicting Social Behaviour. Englewood Cliffs, N.J., Prentice-Hall.

4. Ali, G.,\& Magalhaes, R., (2008). Barriers to implementing e-learning: a Kuwaiti case study. International Journal of Training and Development. 12(1), 36-53

5. Ally, M. (2004). Foundations of Educational Theory for Online Learning. Anderson, Terry in Fathi Elloumni, 3-31.

6. Amin, H. (2009). An analysis of online banking usage intentions: an extension of the technology acceptance model. International Journal Business and Society, 10(1), 27-40.

7. Anderson, J., \& Gerbing, D. (1988). Structural equation modeling in practice: A review and recommended two-step approach. Psychological Bulletin, 103(3), 41123.

8. Ball, D., \& Levy, Y. (2009). Emerging Educational Technology: Assessing the Factors that Influence Instructors' Acceptance in Information Systems and Other Classrooms. Journal of Information Systems Education, 19(4), 431,443.

9. Bates, T. (2005). Strategy and visions of e-learning in higher education. Zagreb. Croatia. URL: http://eqibeltsrce.hr/lectures/bales.html, 10 June 2009. 
10. Becker, H. J. (1999). Internet use by teachers: Conditions of professional use and teacher-centered student use. Irvine, CA: Center for Research on Information Technology and Organizations. Retrieved October 12, 2003, from http:// www.crito.uci.edu/tlc/findings/internet-use/text-tables.pdf.

11. Begiievic, N., Divjak, B., \& Hunjak, T. (2007). Prioritization of e-leaming forms: a multicriteria Methodology. Springer-Verlag. 15:405-419.

12. Bonk, J. C. (Fall, 2000). My hat's on to the online instructor. E-Education Advisor, $10-12$.

13. Bhattacherjee, A., \& Premkumar G. (2004). Understanding Changes in Belief and Attitude Toward Information Technology Usage: A Theoretical Model and Longitudinal Test. MISQ Archivist, 28,2.

14. Bonk, C, Ehman, L., Hixon, E., \& Yamagata-Lynch, L. (2002). The pedagogical TICKIT: Web conferencing to promote communication and support during teacher professional development. Journal of Technology and Teacher Education, 10(2), 205-233.

15. Borstorff, P. C., \& Lowe, S. L. (2007). Student perceptions and opinions toward elearning in the college environment. Academy of Educational Leadership Journal, 11(2), 13-30.

16. Brower, H. (2003). On emulating classroom discussion in a distance-delivered OBHR course: Creating an on-line learning community. Academy of Management Learning and Education, 2(1), 22-36.

17. Byrne, B. M. (1994). Structural Equation Modeling with EQS and EQS/Windows: Basic Concepts, Applications, and Programming. Sage Publications.

18. Campbell, C. R., \& Swift, C. O. (2006). Perceptions of compressed video distance learning (DL) across location and levels of instruction in business courses. Journal of Education for Business, 81(3), 170-174.

19. Cassidy, S., \& Eachus, P. (2002). Developing the Computer User Self-Efficacy (CUSE) Scale: Investigating the Relationship Between Computer Self-Efficacy, Gender and Experience with Computers. Journal of Educational Computing Research, 26(2), 169-189.

20. Chatterjee, D., Grewal, R., \& Sambamurthy, V. (2002). Shaping up for Ecommerce: Institutional enablers of the organizational assimilation of web technologies. MIS Quarterly, 26, 65-89.

21. Chen, R. S., \& Hsiang, C. H. (2007). A study on the critical success factors for corporations embarking on knowledge community-based e-learning. Information Sciences, 177 2, 570-586.

22. Cheong, J. H., \& Park, M. C. (2005). Mobile Internet acceptance in Korea. Internet Research, 15, 125-140.

23. Cho, I., \& Kim, Y. (2001). Critical factors for assimilation of object-oriented programming languages. Journal of Management Information Systems, 18(3), 125156.

24. Christensen, R. (2002). Effects of Technology Integration Education on the Attitudes of Teachers and Students. Journal of Research on Technology in Education, 34(4), 411-433.

25. Concannon, F., Flynn, A., \& Campbell, M. (2005). What campus-based students think about the quality and benefits of e-learning. British Journal of Educational Technology, 36(3), 501-512. 
26. Chang, M. K., \& Cheung, W. (2001). Determinants of the Intention to Use Internet/WWW at Work: A Confirmatory Study. Information and Management, 39(1), 1-14.

27. Dabholkar, P. A. (1994). Incorporating Choice into an Attitudinal Framework: Analyzing Model of Mental Comparison Process. Journal of Consumer Research, $21,100-18$.

28. Davis, F. D. (1989). Perceived Usefulness, Perceived Ease of Use, and User Acceptance of Information Technology. MIS Quarterly, 13(3), 318-339.

29. Davis, F. D., Bagozzi, R. P. and Warshaw, P. R. (1989). User Acceptance of Computer Technology: A Comparison of Two Theoretical Models. Management Science, 35(8), 982-1003.

30. Davis, F. D., Bagozzi, R. P., \& Warshaw, P. R. (1992). Extrinsic and intrinsic motivation to use computers in the workplace. Journal of Applied Social Psychology, 22, 1111-1132.

31. Delcourt, M. A. B., \& Kinzie, M. B. (1993). Computer Technologies in Teacher Education: The Measurement of Attitudes and Self-Efficacy. Journal of Research \& Development in Education, 27, 35-41.

32. Dillon, A., \& Morris, G. M. (1996). User Acceptance of Information Technology Theories and Models. In M. Williams (ed.) Annual Review of Information Science and Technology, 31, Medford, NJ: Information Today, pp. 3-32.

33. Elliott, M. T., \& Frank, Q. F. (2008). Consumer Acceptance of Technology Products: The Impact of Tactical Selling Approaches. Marketing Management Journal, 18(2), 48-65.

34. Fishbein, M., \& Ajzen, I. (1975). Belief, Attitude, Intention and Behavior: An Introduction to Theory and Research. Reading, MA, Addison-Wesley.

35. Fuller, M., Robert, V. C., \& Brown, A. S. (2006). E-learning and Individual Characteristics: The Role of Computer Anxiety and Communication Apprehension. Journal of Computer Information Systems, 46, 103-115.

36. Hair. J., Anderson, R., Tatham. R., \& Black, W. (1992). Multivariate Data Analysis, 2nd Edition. Macmillan. New York..

37. Hammer, M., \& Champy J. (2001). Reengineering the Corporation: A Manifesto for Business Revolution. Nicholas Brealey Publishing: London.

38. Hong, W., Wong, W., Thong, J., \& Tam, K. (2002). Determinants of user acceptance of digital libraries: An empirical examination of individual differences and system characteristics. Journal of Management Information Systems, 18(3), 97-124.

39. Howard, G. S. (1986). Computer anxiety and the use of microcomputers in management. Ann Arbor, MI: UMI Research Press.

40. Hu, J. H., Chau, Y. K. et al. (1999). Examining Technology Acceptance Model Using Physician Acceptance of Telemedicine Technology. Journal of Management Information Systems, 16(2), 91-112.

41. Hung, H., \& Cho, V. (2008). Continued usage of e-learning communication tools: a study from the learners' perspective in Hong Kong. International Journal of Training and Development, 12, 171-187.

42. Hung, S. Y., Ku, C. Y., \& Chang, C. M. (2002). Empirical Test of the WAP Adoption Model. working paper. Department of Information Management, National Chung Cheng University, Chia-Yi. 
43. Igbaria, M., \& Iivari, J. (1995), The Effects of Self-Efficacy on Computer Usage. Omega. International Journal of Management Science, 23(6), 587-605.

44. Igbaria, M., Zinatlli, N., Cragg, P., \& Cavaye, A. (1997). Personal Computing Acceptance Factors in Small Firms: A Structural Equation Model. MIS Quarterly, 21(3), 279-305.

45. James, M. L. (1997). Delivering the MBA via the Internet: Where do we begin? Academy of Educational Leadership Journal, 1, 41-46.

46. Karahanna, E., Agarwal., R., \& Angst, C. (2006). Reconceptualizing Compatibility Beliefs in Technology Acceptance. Available at SSRN: http://ssrn.com/abstract=1273161.

47. Karahanna, E., \& Straub, D. W. (1999). The psychological origins of perceived usefulness and ease of use. Information and Management, 35, 237-250.

48. Kartha, C. P. (2006, September). Learning business statistics vs. traditional. Business Review, 5, 27-33.

49. Keeler, C. M., \& R. Anson. (1995). An Assessment of Cooperative Learning Used for Basic Computer Skills Instruction in the College Classroom. Journal of Educational Computing Research, 12(4), 379- 393.

50. Keller, J. B., Ehman, L. H., \& Bonk, C. J. (2003). Professional development that increases technology integration by K-12 teachers: Influence of the TICKIT program. Paper presented at the American Educational Research Association annual meeting, Chicago, IL.

51. Kelz., A. (2009). E-Learning Strategies in Technical Part-Time Studies at Campus Pinkafeld: A Moderate Constructivist Approach to Learning and Teaching. International Journal of Advanced Corporate Learning. 2(1), 25-30.

52. Kleijnen, M., Wetzels, M., \& de Ruyter, K. (2004). Consumer acceptance of wireless finance. Journal of Financial Services Marketing, 8, 206-217.

53. Koufaris, M. (2002). Applying the technology acceptance model and flow theory 'to online consumer behavior. Information Systems Research, 13, 205-223.

54. Lai, M., L., \& Chong, M., M. (2007). Professional students' technology readiness, prior computing experience and acceptance of an e-learning system. Malaysian Accounting Review; 6, 1, 85-99.

55. Legris, P., Ingham, J., \& Collerette, P. (2003). Why Do People Use Information Technology? A Critical Review of the Technology Acceptance Model. Information and Management, 40, 191-204.

56. Liang, H., Saraf, N., Hu, Q., \& Xue, Y. (2007). Assimilation of enterprise systems: The effect of institutional pressures and the mediating role of top management. MIS Quarterly, 31, 59-87.

57. Liaw, S., Huang, H., \& Chen, G. (2007). An activity-theoretical approach to investigate learners' factors toward elearning systems. Computers in Human Behavior , 23, 1906-1920.

58. Liu,Y., \& Wang, H. (2009). A comparative study on e-learning technologies and products: from the East to the West. Systems Research \& Behavioral Science, 26(2), 191-209.

59. Loyd, B., H., \& Gressard, C. (1994). Reliability and factorial validity of computer attitude scales. Educational and Psychological measurement. 44, 501-505. 
60. Moore, G. C., \& Benbasat, I. (1991). Development of an instrument to measure the perceptions of adopting an information technology innovation. Information Systems Research, 2, 192-222.

61. Nysveen, H., Pedersen, P. E., \& Thorbjornsen, H. (2005). Explaining intention to use mobile chat services: Moderating effects of gender. Journal of Consumer Marketing, 33, 247-256.

62. Qi, J., Li, L., Li, Y. \& Shu, H. (2009). An Extension of Technology Acceptance Model: Analysis of the Adoption of Mobile Data Services in China. Systems Research and Behavioral Science Syst, 26, 391-407.

63. Ong, C. H. \& Lai, J. Y. (2006). Gender differences in perceptions and relationships among dominants of e-learning acceptance. Computers in Human Behavior 22(5), 816-829.

64. Parthasarathy, M., \& Bhattacherjee, A. (1998). Understanding Post-Adoption Behavior in the Context of Online Services. Information Systems Research, (9:4), 362-379.

65. Pituch, K. A., \& Lee, Y. (2006). The Influence of System Characteristics on ELearning Use. Computers \& Education, 47(2), 222-244.

66. Porter, C., \& Naveen, D. (2006). Using the Technology Acceptance Model to Explain How Attitudes Determine Internet Usage: The Role of Perceived Access Barriers and Demographics. Journal of Business Research, 9, 999-1007.

67. Rogers, E. M. (1995). Diffusion of Innovations (4th ed.), The Free Press, New York.

68. Rosen, L. D., Sears, D. C., \& Weil, M. M. (1993). Treating technophobia: A longitudinal evaluation of the computerphobia reduction program. Computer in Human Behavior, 9, 27-50.

69. Rossiter, D. (2007). Whither e-learning? Conceptions of change and innovation in higher education. Journal of Organisational Transformation and Social Change, 4(1), 93-107.

70. Rovai, A. P., \& Childress, M. D. (2002). Explaining and predicting teacher education students who are resistant to computer anxiety reduction. Journal of Research on Technology in Education, 35(2), 226-235.

71. Russell, T. L. (2001). The No Significant Difference Phenomenon: A Comparative Research Annotated Bibliography on Technology for Distance Education. IDECC - International Distance Education Certification Center,

72. Shurville, S., \& Browne, T. (2006). ICT-driven change in higher education: Learning from e-learning. Journal of Organisational Transformation and Social Change, 3(3), 245-250, doi: 10.1386/jots.3.3.245/2.

73. Singleton, E., Song, L., Hill, J., Koh, M., Jones, F. \& Barbour, M. (2004). Online learning: Perceptions of useful and challenging characteristics. In G. Richards (Ed.). Proceedings of World Conference on E-learning in Corporate, Government, Healthcare, and Higher Education (pp. 946-950). Chesapeake, VA: AACE.

74. Smith, B., Caputi, P., Crittenden, N., Jayasuriya, R., \& Rawstorne, P. (1999). A Review of the Construct of Computer Experience. Computers in Human Behavior, 15(2), 227-242.

75. Sul־ $\mathrm{ci}^{\mathrm{c}} \mathrm{c}, \mathrm{V}$. (2007). Is e-learning more suitable for full-time or for part-time students? In Technologies for Business InformationSystems, ed. Abramowicz W., Mayr, H.C.. Heidelberg: Springer Verlag. 
76. Sun, P. C., Tsai, R. J., Finger, G., Chen, Y. Y., \& Yeh, D. (2008). What drives a successful elearning? An empirical investigation of the critical factors influencing learner satisfaction. Computers \& Education, 50(4), 1183-1202.

77. Swan, K., Holmes, A., Vargas, J. D., Jennings, S., Meier, E., \& Rubenfeld, L. (2002). Situated professional development and technology integration: The Capital Area technology and inquiry in education (CATIE) mentoring program. Journal of Technology and Teacher Education, 70(2), 169-190.

78. Symonds, W. (2003). University of Phoenix Online: Swift Rise. BusinessWeek Online, June 23, www.businessweek.com.

79. Tao, Y. H., Yeh, C. R., \& Sun, S. I. (2006). Improving training needs assessment processes via the Internet: system design and qualitative study. Internet Research, 16(4), 427-49.

80. Taylor, S., \& Todd, P. (1995). Understanding Information Technology Usage: A Test of Competing Models. Information Systems Research, 6(2), 144-176.

81. Tham, C., \& Werner, J. (2005). Designing and Evaluating E-Learning in Higher Education: A Review and Recommendations. Journal of Leadership and Organizational Studies, 11(2), 15-25.

82. The Jordan Times.(2009). Mobile Phone Penetration.

83. Thompson, R., Compeau, R. D., \& Higgins, C. (2006). Intentions to Use Information Technologies: An Integrative Model. Journal of Organizational and End User Computing. 18(3), 25-47.

84. Todman, J., \& Monaghan. E. (1994). Qualitative Differences in Computer Experience, Computer Anxiety, and Student's Use of Computers: a Path Model. Computers in Human Behavior, 10(4), 529-539.

85. Tung, F. C., \& Chang, S. C. (2008). An empirical investigation of students' behavioral intentions to use the online learning course websites. British Journal of Educational Technology, 39(1), 71-83.

86. Venkatesh, V. (2000). Determinants of perceived ease of use: Integrating perceived behavioral control, computer anxiety and enjoyment into the technology acceptance model. Information Systems Research, 11, 342-365.

87. Venkatesh, V., \& Bala, H. (2008). Technology Acceptance Model 3 and a Research Agenda on Interventions. Decision Sciences , (39:2), 273-315.

88. Venkatesh, V., \& Morris, M. G. (2000). Why don't men ever stop to ask for directions? Gender, social influence, and their role in technology acceptance and usage behavior. MIS Quarterly, 24, 115-139.

89. Venkatesh, V., Davis, F. D., \& Morris, M. G. (2007). Dead or alive? The development, trajectory and future of technology adoption research. Journal of the Association for Information Systems, 8, 267-286.

90. Venkatesh, V., Morris, M. G., Davis, G. B., \& Davis, F. D. (2003). User acceptanceof information technology: Toward a unified view. MIS Quarterly, 27, $425-478$.

91. Wang, Y. S., Wang, Y. M., Lin, H. H., \& Tang, T. I. (2003). Determinants of user acceptance of Internet banking: An empirical study. International Journal of Service Industry Management, 14, 501-519.

92. Webster, J., \& Hackley, P. (1997). Teaching effectiveness in technology-mediated distance learning. Academy of Management Journal, 40(6), 1282-1309. 
93. Wentling, T. L., Waight, C., Gallagher, J., La Fleur, J., Wang, C., \& Kanfer, A. (2000). E-learning - a review of literature. Knowledge and Learning Systems Group NCSA 9. 1-73.

94. Yang, H. H., Mohamed, D., \& Beyerbach, B. (1999). An Investigation of Computer Anxiety among Vocational-Technical Teachers. Journal of Industrial Teacher Education, 37(1), 64-82.

95. Zapalska, A., Shao, L. P., \& Shao, D. J. (2003). Evaluating the effectiveness of WEBCT using student feedback. Academy of Educational Leadership Journal, 7(1), 91-102.

96. Zemsky, R.. (2007). E-learning: Successes and Failures. Chronicle of Higher Education, 53(18), 1-5.

97. Zhao, Y., \& Frank, K. A. (2003). An ecological analysis of factors affecting technology use in schools. American Educational Research Journal, 40, 807-840. 